\title{
Tradition and Creativity of the Rahu Symbol in Buddhist Temples: Case Study of Paintings, Sculptures and Amulets in Central and East of Thailand
}

\author{
Prasirt Runra (ประเสริฐ รุนรา) \\ Lecturer, Faculty of Liberal Arts, Thammasat University, Thailand \\ runra.prasirt@gmail.com \\ Sukanya Sujachaya (สุกัญญา สุจฉายา) \\ Independent researcher \\ maemee5o@gmail.com
}

\begin{abstract}
The objective of the study was to analyze the transmission and application of Rahu symbolism in contemporary Thai society. Data was collected from both documents and a field study in central and eastern Thailand. It was found that in traditional Thai art, the Rahu symbol is portrayed as his face swallowing the sun or the moon. This kind of Rahu symbol is found in Buddhist temples. Such appearances of the Rahu symbol are related to the belief that Rahu has a protective function. Interestingly, the sculpture of Rahu's body rather than only his face has become popular in contemporary Thai society. Nowadays, Rahu sculptures tend to be located in specific places. A ritual of worshipping Rahu is often created with offerings of food generally of black color. In addition, the Rahu symbol is now created in several other forms such as posters, magic cloths and amulets. Such newly created art forms of Rahu are due to modern interpretations and meanings of the Rahu symbol in contemporary Thai society. These newly-developed meanings of the Rahu symbol are interesting since they can be applied to deal with people's problems in the socio-cultural and political context of contemporary Thai society.
\end{abstract}

(C) PRASIRT RUNRA AND SUKANYA SUJACHAYA, 2019 | DOI:10.1163/26659077-02202006

This is an open access article distributed under the terms of the prevailing CC-BY-NC License at the time of publication. 


\section{Keywords}

Rahu - Symbol - Thai Art

\section{บทคัดย่อ}

ประเพณีและความคิดสร้างสรรค์สัญลักษณ์ราหูในพุทธสถาน: กรณีศึกษาจิตรกรรม ประติมากรรมและพระ เครื่องในเขตภาคกลางและภาคตะวันออกของประเทศไทย

การศึกษาครั้งนี้มีวัตถุประสงค์เพื่อวิเคราะห์การสืบทอดและการใช้สัญลักษณ์ราหูในสังคมไทยร่วมสมัย โดยเก็บข้อมูลจาก เอกสารและจากภาคสนามในพื้นที่ภาคกลางและภาคตะวันออกของประเทศไทย จากการศึกษาพบว่า สัญลักษณ์ราหูส่วนใหญ่ ปรากฏให้เห็นส่วนหัวที่กำลังทำท่าจะจับหรือกลืนอาทิตย์หรือดวงจันทร์และประดิษฐานอยู่ในศิลปะไทยโบราณในวัดในพุทธ ศาสนา ทั้งนี้สัญลักษณ์พระราหูเหล่านี้เกี่ยวข้องกับความเชื่อที่ว่า ราหูมีหน้าที่ป้องกันพุทธสถานหรือเป็นสัญลักษณ์ประกอบ ของจักรวาล ในปัจจุบันมีความน่าสนใจเนื่องจากมักจะมีการสร้างรูปปั้นราหูและจัดวางในสถานที่ที่เป็นศาลาหรือโรงเฉพาะเพื่อ ใช้ประกอบพิธี ในการทำพิธีกรรมการบูชาราหูมักจะบูชาหรือบนด้วยอาหารที่มีสีดำ นอกจากนี้ยังมีสิ่งของที่เป็นสัญลักษณ์ราหู ที่สร้างขึ้นในรูปแบบอื่น ๆ เช่นโปสเตอร์ผ้าวิเศษและเครื่องราง รูปแบบศิลปะที่สร้างขึ้นใหม่ของราหูนั้นเกิดจากการตีความและ สร้างความหมายใหม่ให้กับราหู ความหมายที่พัฒนาขึ้นใหม่นี้มีความน่าสนใจ เพราะแสดงให้เห็นการนำสัญลักษณ์ดั้งเดิมใน วัฒนธรรมมาประยุกต์ใช้เพื่อแก้ไขปัญหาของผู้คนในบริบททางสังคม วัฒนธรรมและการเมืองของสังคมไทยร่วมสมัย

\section{Introduction ${ }^{1}$}

According to Hindu mythology, Rahu has the body of asura who is perceived as an opponent of devas. There are many fighting scenes between asuras and devas in Indian epics. Certainly, the most well-known myth associated with asuras and devas is the story of the 'Churning of the Ocean' which is related to Rahu (Chandrasekharam 2007: 30) according to the legend as narrated in the Mahabharata and Puranas.

In Thailand, belief in Rahu is influenced by Hinduism combined with Buddhism and also local faiths. Rahu assumes the image of the villain. Incidentally, Rahu is perceived also as the symbol of a bad year and as the god of Wednesday night, a time of misery (Chandanahom, 1966: introduction 21). Therefore, Rahu is a symbol of evil omen or bad luck and is usually related to undesirable events.

Thai society recognizes Rahu as the asura who has a black half body and is often depicted as swallowing the sun or the moon. This image, depicted

1 (The research for this article was partially funded by the TRF Research Grant for the New Scholar project). 
in many Thai mural paintings, sculptures and so on relates to the Hindu mythological scene of churning the milk ocean into an elixir (Chandrasekharam 2007: 30). In the ritual, Rahu tried to steal the elixir. The sun god and the moon god saw this and told Vishnu, who cut Rahu's body into two halves. Thus, Rahu has only a half body but since he had already drunk the elixir he is immortal. Rahu was angry with the sun god and the moon god, so whenever he saw the two gods he would try to eat them. This story has become the explanation for the natural phenomena of solar and lunar eclipses. Therefore, the Hindu myth became the subject matter of mural paintings and other forms of art. And via these works of art, the myth has been disseminated within Thai society.

In Thai art, mural paintings and sculptures from the Sukhothai, Ayutthaya and Rattanakosin eras show the depiction of Rahu variously through time and the meaning of the Rahu symbol has been interpreted in many ways.

This research studies the various dynamic meanings of the Rahu symbol in Thai art and investigates and analyzes the transmission and application of Rahu symbolism in contemporary Thai society. Data was collected from both documents and field studies concerning the Rahu symbol in Thai art in central and eastern areas of Thailand. The results will generate a comprehensive understanding of dynamic beliefs concerning Rahu from the past to the present and explain why belief in Rahu has remained strong throughout the history of Thai society with reproductions in various forms.

\section{$2 \quad$ Objectives}

To study the traditional elements and new components of the Rahu Symbol in Thailand and to examine how these new components reflect changing beliefs concerning the god, Rahu.

\section{Scope of Study}

The study focuses on two types of Rahu symbol in Buddhism: traditional and creative.

1) The author gathered Thai arts that display the Rahu symbol from mural paintings since the Ayutthaya period; the total number of studied temples was six as follows: 

1. Wat Na Phra Meru
Ayutthaya
2. Wat Phutthisawan
Ayutthaya
3. Wat Koh Kaew Suttharam
Phetchaburi
4. Wat Maha That Worawiharn
Ratchaburi
5. Wat Ratchasittharam Ratchaworawiharn
Bangkok
6. Wat Phra Chettuphon Wimonmangkhlaram
Bangkok

2) The author gathered Thai creative art sculptures of the Rahu symbol with field data collected from the temples in the central region and the eastern region where the myth of Rahu is widespread. The scope of information specified that they must be large sculptures and the areas must perform the Rahu ritual. The total number of studied temples was 20, as follows:
1. Wat Srisathong
Nakhon Pathom
2. Wat Ang Sila
Chonburi
3. Wat Khao Sok
Chonburi
4. Wat Huai Yai
Chonburi
5. Wat Tho Yai
Chonburi
6. Wat Chong Samae San
Chonburi
7. Wat Ta mai
Samut Sakhon
8. Wat Ta Krabeu
Samut Sakhon
9. Wat Bang Ya Praek
Samut Sakhon
10. Wat Lak Si Rat Samoson
Samut Sakhon
11. Wat Bangchak
Nonthaburi
12. Wat Khunjan
Bangkok
13. Wat Chao Am
Bangkok
14. Wat Tai Mitra
Bangkok
15. Wat Samanrattanaram
Chachoangsao
16. Wat Sanamchandr
Chachoangsao
17. Wat Nong-or
Chanthaburi
18. Wat Sralong-ruea
Kanchanaburi
19. Wat Padhammasophon
Lopburi
20. Wat Bang Sao Thong
Samutprakan

The author gathered information on Thai arts as displayed in the creativity of Rahu symbols from reports of mural paintings and prints created after the year 1997. 
4 Methodology

The author selected documentary research and field studies as the folklore methodology, including field studies and participant observations in the studied areas with the following processes:

1) Research and literature review of the symbol analysis and astrological ideas

2) Research and literature review about mural paintings in ancient Thai records and mural paintings, state documents, studying documents, research and articles for the comprehension of history, background, physical area and an overview of each local community.

3) Data received from observation and intermittent collection in field studies from July 2015 to November 2016

4) Revise and report the result of the data analysis and present the research by descriptive analysis.

\section{$5 \quad$ Literature Review}

According to the literature view, the author collected information from anthropological research about Rahu which focuses on studying the worshiping ritual of Rahu; the Buddhist research which mainly studies the legend of Rahu in Tripitaka and Atthakatha; the archaeological research that emphasizes the history of Rahu belief in some areas, as follows:

Phungpracha (2002) writes about Rahu: "the invented tradition" of Wat Srisathong in a dissertation for Master of Sociology and Anthropology. This dissertation studied the worshiping ritual of Rahu within the scope of "the invented tradition". In conclusion, the ritual of Wat Srisathong originated from traditional beliefs about Rahu which relate to Lao Wieng ancestors at Wat Srisathong. Moreover, with the new reference to the building of the new form of Rahu ritual, Wat Srisathong has been named to be the origin of Rahu belief.

Dhammahaso (2005) writes "Conjunction of Moon and Sun: Study on Analysis and Interpretation". This thesis describes the belief in the conjunction of the moon and the sun by researching from Tripitaka and Atthakatha in order to affirm the belief in the sun deity and the moon deity relating to Rahu truly appearing in Buddhism as in Hinduism. However, the physical appearance of Rahu in Hinduism has two separate parts of bodies while there is no description in Buddhism. Furthermore, in the Buddhist religion, they regard Rahu as 
evil and cruel and, in the end, he becomes the Upasaka (the follower of Buddhism) who cherishes the triple gems.

In terms of reliance on Dhamma, the interesting story of the relationship between Rahu, the Moon Deity and the Sun Deity is the manifestation of the great power of Lord Buddha, which means that relying on the Buddha's words will save one from danger in the same way as the sun deity and the moon deity who survived Rahu by recalling the Lord Buddha. This idea has its part in support of the faith that a person, who has not sufficient Dhamma in themselves when recalling the Lord Buddha and the deity, can develop themselves for Nirvana as well. This is because this method is an emotion of a mediation of 40 concentrations.

Marktawee (2010) terms the concept of the "Rahu" demon in Lao culture in North-Eastern Thailand Independent Study. This research studied the belief in Rahu in the North-East and it found that the belief in Rahu appears in the myths of provinces, for example, Rahu is the Asura deity and demonstrates his power to the Moon-god by swallowing him until humans must hit objects to chase him away. This myth relates to frog-eats-moon. The moon is the servant of Indra. When an old man asks a frog to help Indra during the heavens' war, the phenomenon of a frog eating the moon occurs. This myth is reflected through the arts in the North-Eastern region, for instance, in sculpture, E-san mural painting and coconut shell art.

With regard to the literature review, there has been no research performed regarding the traditional elements and new components of the Rahu Symbol in Thailand and how these new components reflect changing beliefs concerning the god, Rahu, in current Thai society.

\section{Research Findings}

The Rahu symbol tradition is represented through sculptures and mural paintings; the evidence is found in the Ayutthaya period to Rattanakosin period. Until the present day, the tradition has been found as the Rahu sculpture at the entrance to Buddhist places and mural paintings about Rahu, the Sun deity, and the Moon deity, which often appear on mural paintings in ordination halls. These two types of art still remain to the present day. Nonetheless, the symbols of Rahu in ancient Thai records were discovered only in the Ayutthaya period to the Thonburi period, due to the fact that ancient records have not been used and the illustrations of art in books has changed because of the evolution of technology. 


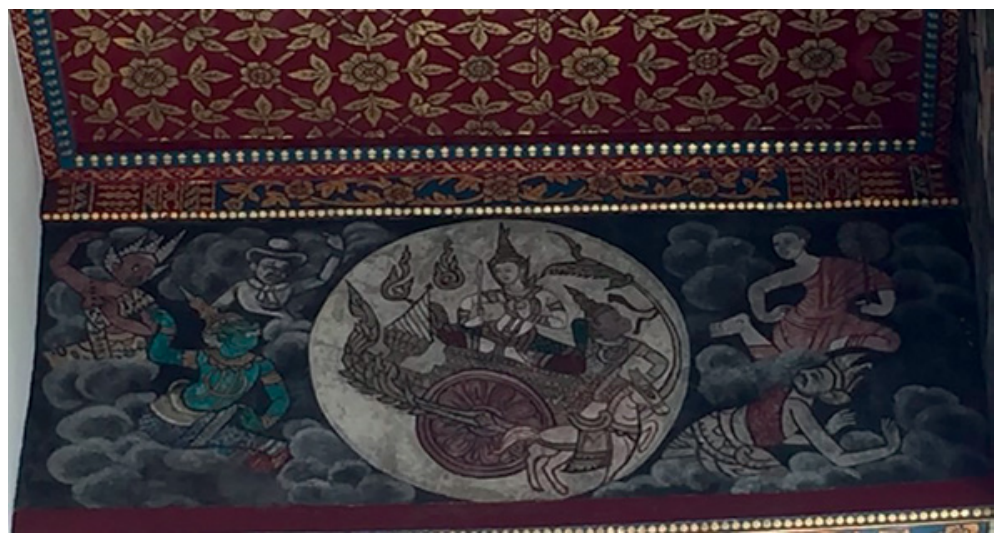

FIGURE 1 The painting of Rahu in the ordination hall of Wat Pho

From documents and data collected during the field research, the Rahu symbol has not only been transmitted in its original form but has also been recreated in various new designs. The factors relating to the transmission and recreation of the symbol of Rahu in Thai art have been analyzed to explain the persistence of the Rahu symbol and beliefs.

In the dimension of Thai culture, Rahu penetrates various things appearing in the society until becoming familiar to people in the society. Relating to this issue, the researcher will obviously present how to create the symbol representing beliefs about Rahu that appear in a cultural context in the perception of people in the society. These are, namely, Rahu with a Buddha image, Rahu with representative color, Rahu with letters and numbers and Rahu with the Paritra praying rhyme.

\subsection{Rahu with Buddha image}

The Buddha image in the posture of Buddha receiving offerings from an elephant and a monkey is related to Rahu as the birthday Buddha image for those who were born on Wednesday night which is the time of Rahu as explained in the Brahmajati Book, "if being born on Wednesday night, worship the Buddha image in the posture of Buddha receiving offerings from an elephant and a monkey" (Hong Hon Sri Mahapho 2002: 175). 


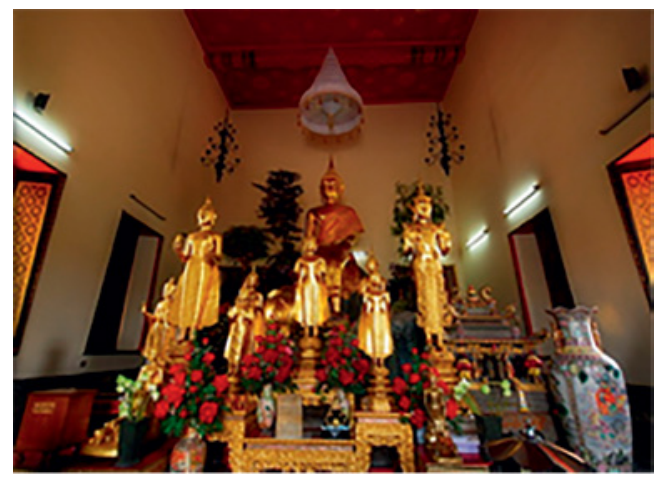

FIGURE 2

Parileyyaka posture at Wat Pho

Another concept in building a Buddha image related to Rahu is to build the Buddha image in the posture of the Reclining Buddha and the big Buddha. Such concepts in building Buddha images cause the Rahu symbol to appear in the area behind the Buddha image. This represents the Asurinthra Rahu that always surrenders to the Buddha's power. The important example is the reclining Buddha image in Wat Phra Chetuphonbuilt in the reign of King Rama III (Fine Arts Department 2015: 28)

\subsection{Rahu with Color}

Rahu is related to the color black especially the color of Rahu's body. In Thai modern art, the color of Rahu's body is often black. The researcher considers the color is the symbol of the unknown as black is a color invisible for the part of the real color inside. It is the color of the night when men cannot see things. Therefore, the color black is a symbol that leads to interpretations associated with fear. Black is the symbol of fear. Using the color black to represent Rahu depicts the emotions of fear in the human mind. Moreover, if the ritual is conducted with veneration in color black, it is like eliminating fear from the human mind. (Runra 2014: 228).

\subsection{Rahu with Letters and Numbers}

The letters and numbers VII and IX are used to represent Rahu as a symbol of prophecy in the astrological texts and are symbolized in the ritual of Rahu veneration (Luang Visaldarunkorn 1997: 284-286). Otherwise, because Rahu is often the symbol of the "middle" which is ambiguous, in astrology, the letters in the alphabet group of ambiguity are used; the alphabets Yor, (ย) Ror, (ร) Lor, (ล) Wor, (ว) that are Semi-vowels. 


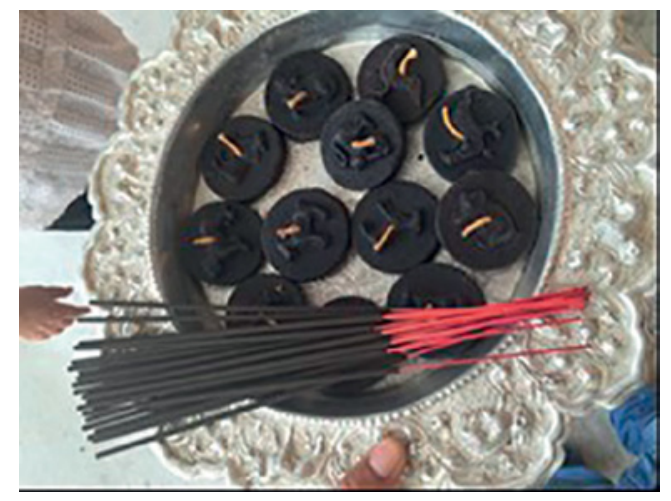

FIGURE 3

The black offerings to Rahu at Wat Tamai

\subsection{Rahu with the Paritr Praying Rhyme}

Atanatiya Paritra, as a mantra for Rahu is a praying rhyme that is invoked for protection (Luang Visaldarunkorn 1997: 828). According to the belief, it is used to prevent harm from the thieves, giants, demons and to avert harm from diseases. Using the Parit praying rhyme to venerate gods and Rahu probably occurred together with the use of the Parit praying rhyme as is evident in the ritual to prolong the age of King Rama IV written by Paramanuchitchinorot.

8

Factors in the Transmission of the Rahu Symbol in Thai Art

The important factors regarding the transmission of the Rahu symbol in art concern the belief in Buddhism and consist of four main concepts. The first is the Buddhist notion concerning the center of the universe and the use of the Rahu symbol as the protection of Buddhist space related to the concept of Tribhumi and cosmology in Thailand. The second is the concept concerning worshipping Rahu as the next Buddha. The third is the astrological perspective. And the last one is popular and related to capitalism.

\section{9}

Buddhist Space as the Center of the Universe

"Buddhist space was an important sacred place as the center for performing community rituals. The concept of cosmology related to the planning and 
construction of sacred places such as cities, temples, palaces and houses. Sometimes, the same strategy and concepts were used to plan ritual sites. This strategy was part of the very ancient cultural heritage which existed in all Indian traditions since the early era." (Snodgrass 1995:14-18)

The concept that a Buddhist temple is sacred and is the center of the universe is followed by people in Indian as well as in Thai society. Royal temples were always constructed with the main chapel representing Mount Meru as the center of the universe since the architectural plan was simulated from Buddhist cosmology.

Firstly, given the concept of the Buddhist space as the center of the universe, Rahu was part of the stars as well as the moon and the sun. Consequently, Rahu was a crucial symbol frequently seen in Thai architecture reflecting a belief in the cosmology as the center of the sacred space.

Secondly, apart from constructing Rahu as a component of the universe, the Rahu symbol also functioned as the one that protects the Buddhist space. Buddhists regard temples as sacred areas under the protection of deities and the symbol of Rahu was constructed to prevent evil from entering the sacred

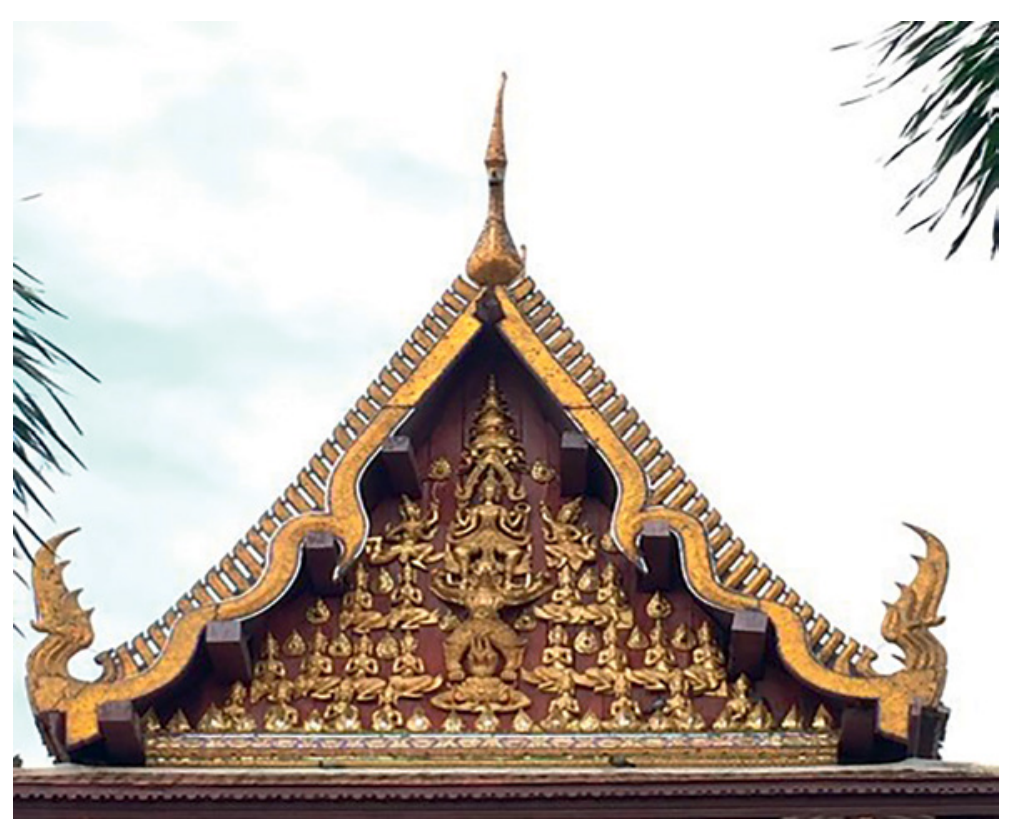

FIGURE 4 Rahu at the ordination hall of Wat Nah Phamen, Ayutthaya 


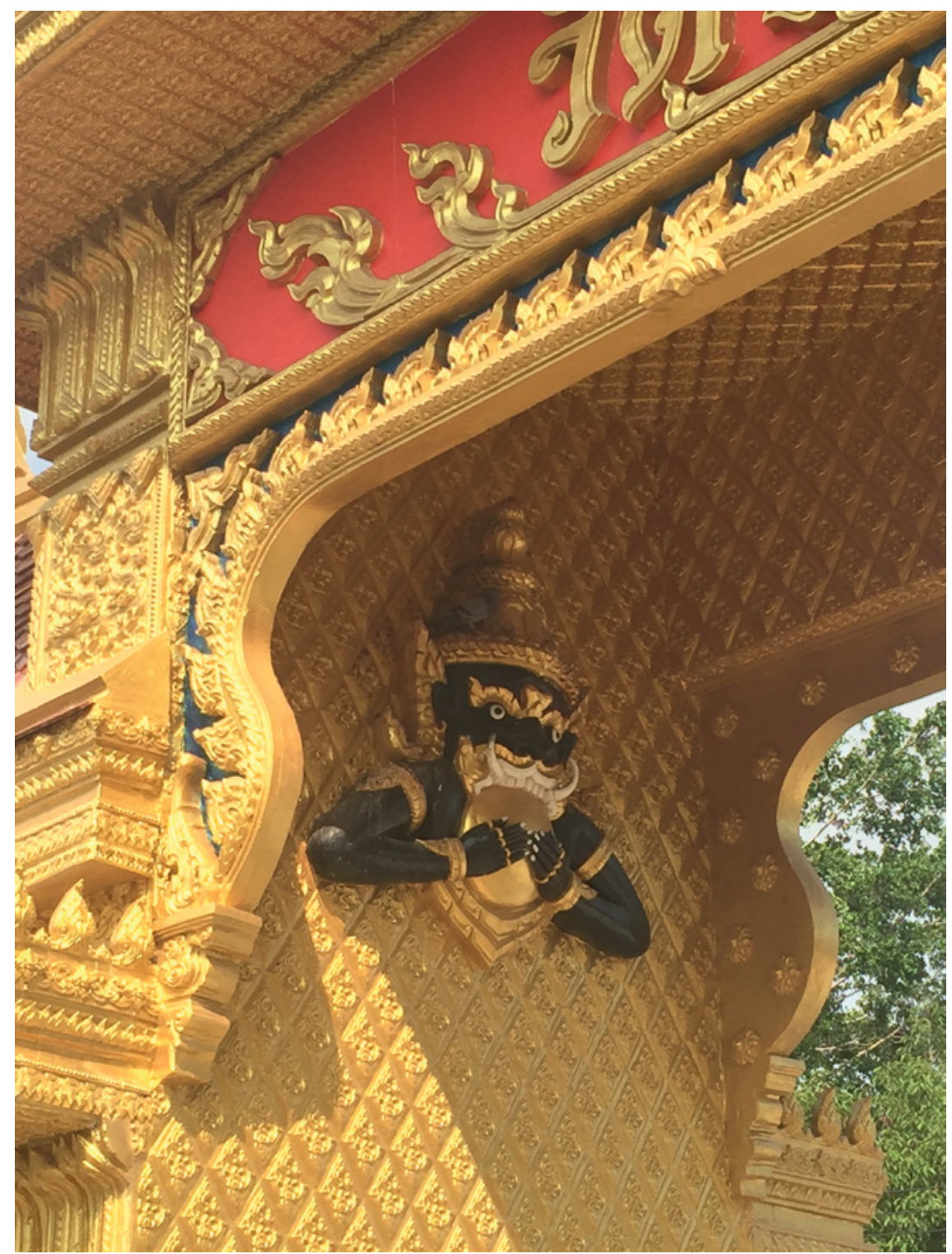

FIGURE 5 Rahu as door-keeper at Wat Nong-or, Chanthaburi

space to disturb the sacred rites. Hence, the symbol of Rahu always exists at the arch or entrance of a Buddhist sacred place. The transmission of the symbol of Rahu through art signifies the god's role as the protector or door-keeper. 


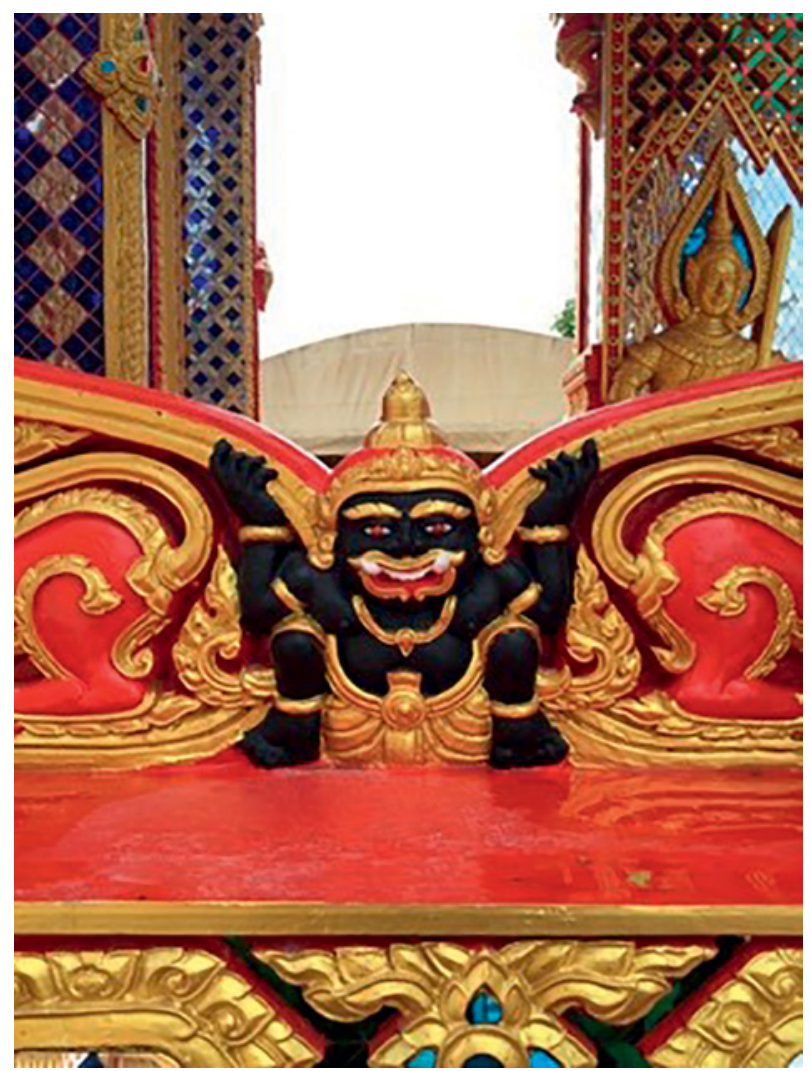

FIGURE 6 Rahu as door-keeper at Wat Huai Yai, Chonburi

\subsection{The Worship of the Next Buddha}

According to the Anagatavamsa book, "Asurindra Rahu is going to be enlightened and become the $5^{\text {th }}$ Buddha named Narada Buddha." (Surasen 1997: 105) Therefore, Rahu is not only the asura who guards sacred Buddhist places but also a Bodhisatta who may become the next Buddha. This concept integrates belief in Rahu and Bodhisattva or the next Buddha and resulted in the transmission of the Rahu symbol in Thai Buddhist art.

These two key concepts are important factors in transmitting the symbol of Rahu in Thai society and can be analyzed through both the art successors and the art consumers. The successors here refer to the art creators, e.g., monks and artists who are determined to transmit the symbol of Rahu to transfer

2 The future Buddha considered Metteyya as the first future Buddha. 


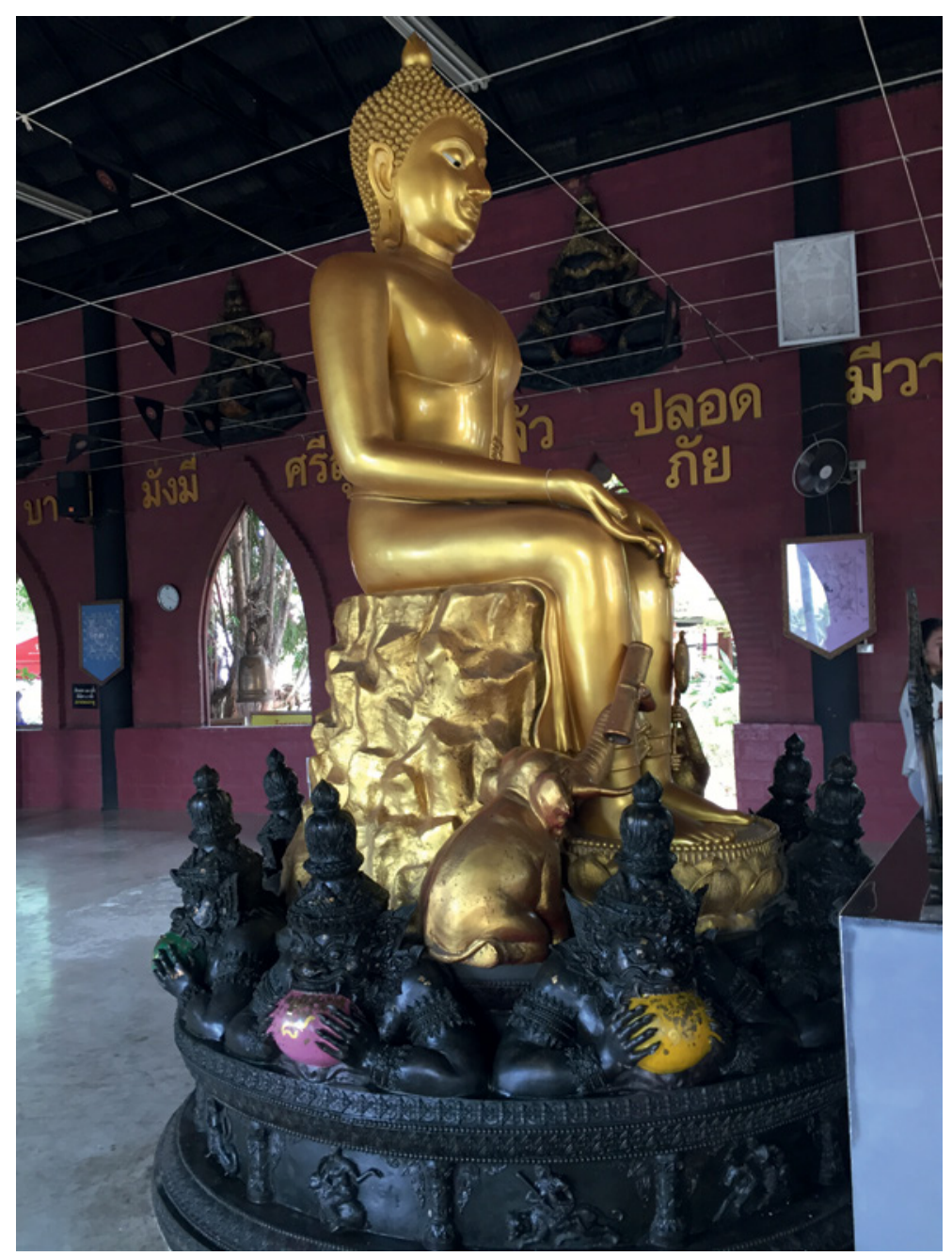

FIGURE 7 Rahu surround the throne of the Lord Buddha at Wat Ta Mai, Samut Sakhon

knowledge and belief in cosmology. The art consumers refer to Buddhists in Thai society who perceive the meaning of Rahu as the sacred god who protects the Buddhist space. Both parties have transmitted the symbol of Rahu as art from generation to generation up to the present day.

\subsection{Astrology}

Thai society has long believed in astrology, especially a belief in luck as related to the way of life. From an astrological perspective, Rahu is related to 
misfortune as a sign of bad luck and sorrow. Thus, the person who designed the symbol interpreted a new definition of Rahu as the deva who dispelled misery.

This was consistent with the demand of art consumers who believe in astrology. They believe that worshipping Rahu helps them to break free from suffering and avoid misfortune. Thus, they worship the Rahu art developed in Thai society to fulfill their psychological needs as believers in astrology.

\subsection{Popular Buddhism and Capitalism}

One important factor that led to the development of the Rahu symbol in Thai society was the characteristics and circumstances of Buddhism. In Thai

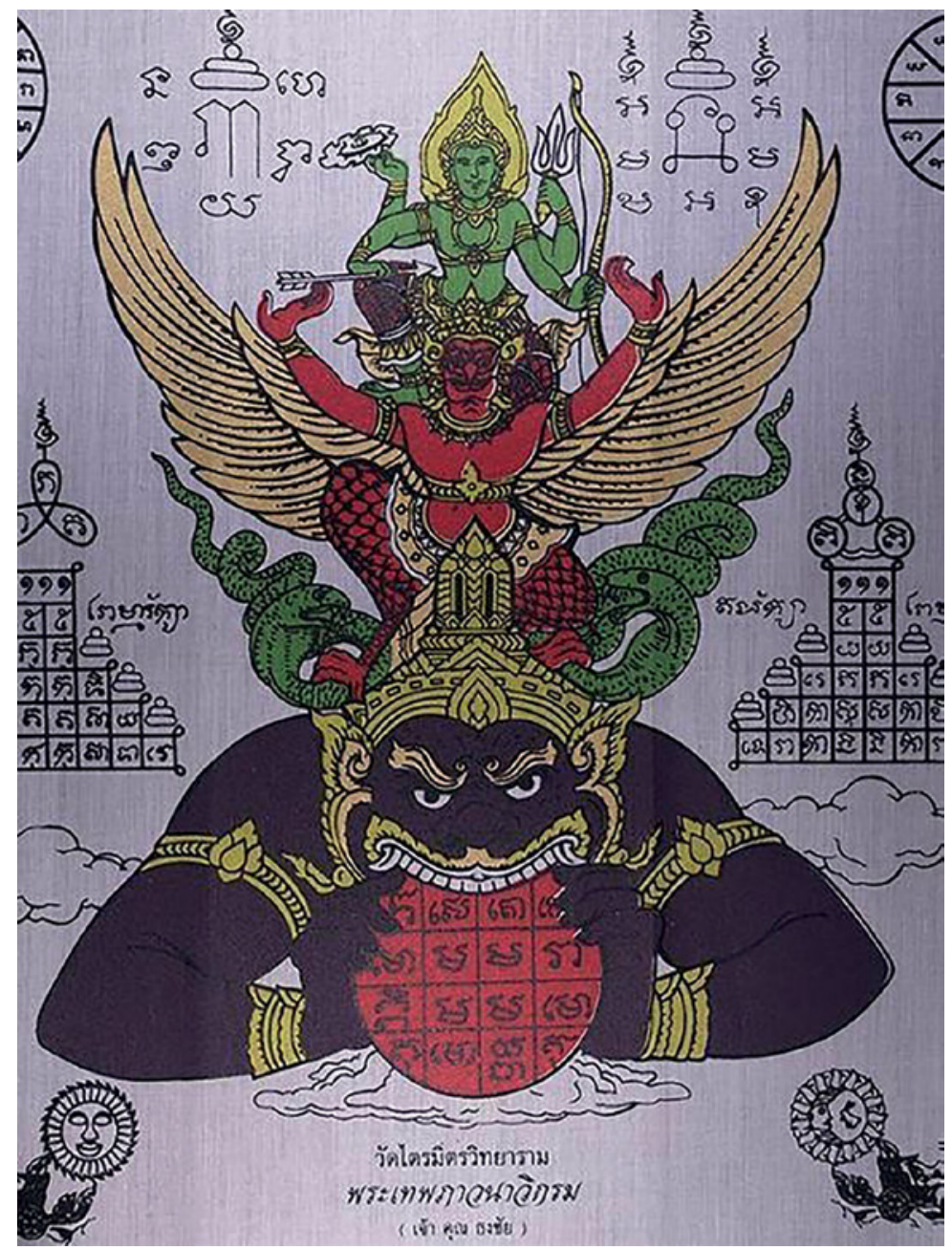

FIGURE 8 Yanta of Wat Tai Mitra, Bangkok 
society, Buddhism is not philosophical or the study of the essence of liberty but the integration of religious concepts and capitalism. Consequently, a religious symbol was designed that led to monetary value. Analysis of the characteristics and circumstances of Buddhism in Thai society was classified into two factors namely populist Buddhism and commercial Buddhism.

10

Popular Buddhism in Thai society

Popular Buddhism was the fundamental Buddhism in Thai society prior to the other Buddhist forms for the agriculturists and "grassroots" people in rural areas who lived life close to nature. Buddhism in the eyes of these people reflects acceptance of restrictions and their inferiority to nature as the mightiness of natural power that delivers both benefits and harm. Faith expanded from religious doctrines to the mysterious power of devas, spirits and ghosts living in natural objects (Sirikanjana 2014: 194).

This was in accordance with the concept of the symbol designer responding to the ethical perception of people in society. Although Buddhism was the main religion in Thai society, populist Buddhism was the acceptable form of Buddhism with its sacred and supernatural power. Rahu was a frightening symbol in the mind. As a result, worship ceremonies to the symbol of Rahu eventually became famous rites in Thai society.

The rite of Rahu-worship, consistent with supernatural powers, was embraced by the upper class who felt frightened and insecure about their status. They believed in Rahu and this doctrine integrated into Thai society and culture at all levels.

\section{Commercial Buddhism in Thai Society}

Commercial Buddhism is a term used by scholars to criticize the belief and faith in Buddhism as a tool to earn money. It is found in various forms such as making votive tablets, amulets, Buddha images and performing rites to earn money such as offering dedications to Buddhist monks, making merit by buying flowers, incense sticks and candles (Bhavakhunworakit 2012: 58).

The circumstances behind developing the symbol of Rahu in current Thai society are likely to have been the result of Buddhist commercials. To create each symbol, the organizer should have fundraising and realize its worthiness. Moreover, the symbol represents the income source earned from the worship or the rites. This factor was considered as a bonus for the organizer who gained 


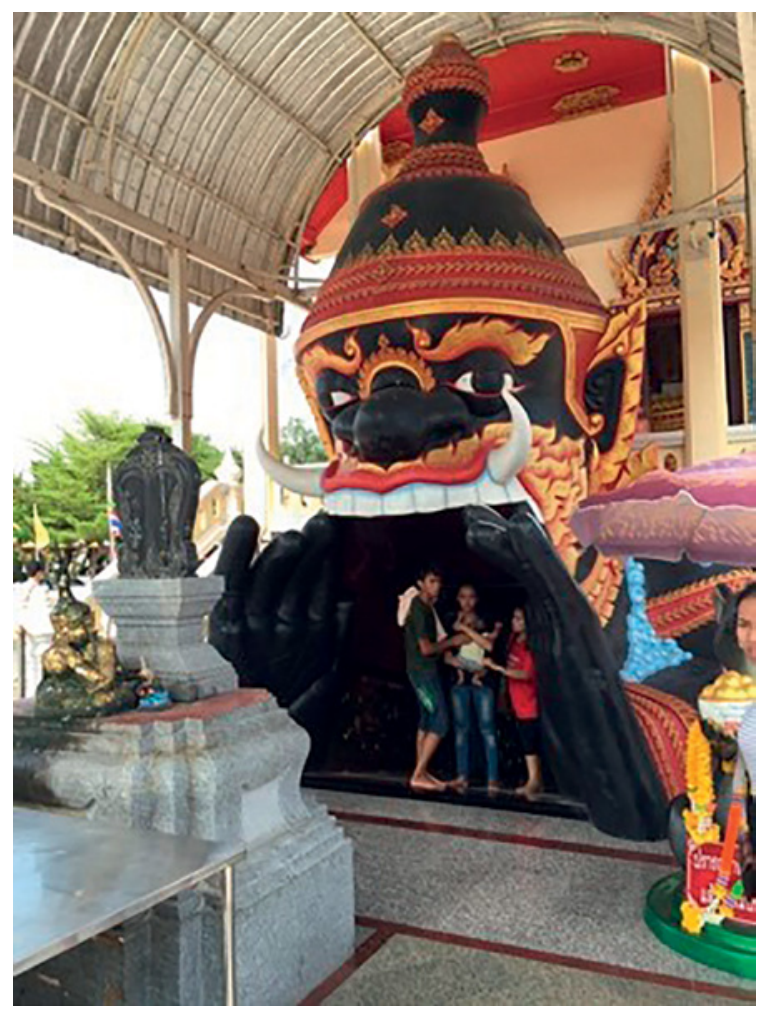

FIGURE 9 Rahu of Wat Chong Samae San, Chonburi

income from the art consumer who needed mental support. Therefore, this factor was a key reason for placing the symbol of Rahu in current Thai society

\section{The Format of Rahu in Current Thai Arts}

In Thailand, the artistic and iconographic evolution of Rahu is complex and intertwined. Each divinity's origins can be traced back to the dawn of Thai traditional text books. Astronomical, astrological and mythological components from diverse cultures meshed together to create the ultimate religious concept of the Rahu. As the data collection of Rahu symbol created nowadays, according to the results, the creation of works appears in two main types of art which are sculptural works and paintings.

Regarding the creation of Rahu symbol in sculptural works, it is evident that the sculptural works of Rahu can be divided into 4 types which are roundrelief, high-relief, bas-relief or incised relief and painting works of Rahu. 


\subsection{Round-relief Sculpture}

According to the collected data, there are 3 characteristics: Ketu as the bottom part, Rahu's half body part and Rahu on Garuda. For the round-relief where the bottom part is Ketu, the author assumes that the today creators receive their influence from astrology in accordance with King Rama IV who found Uranus and mistook it for Ketu that is counted as the tail of Rahu, resulting in the creation of Rahu with Ketu as the bottom part.

For the sculpture of Rahu with a half of body, the author assumes that the creators receive their influence from the myth of Amrita when Rahu was cut into half by the God of Weapons; hence, the works demonstrating only the half body with the mouth full of Amrita or the moon.

Regarding the sculptures of Rahu on Garuda, the author has discovered that the creator was a famous astrologer. The author assumed that this creation aims at making the new difference of the other Rahu. In addition, this character may build and attract people better than the other fearful appearance. Furthermore, the new definition of this symbol sounds favorable.

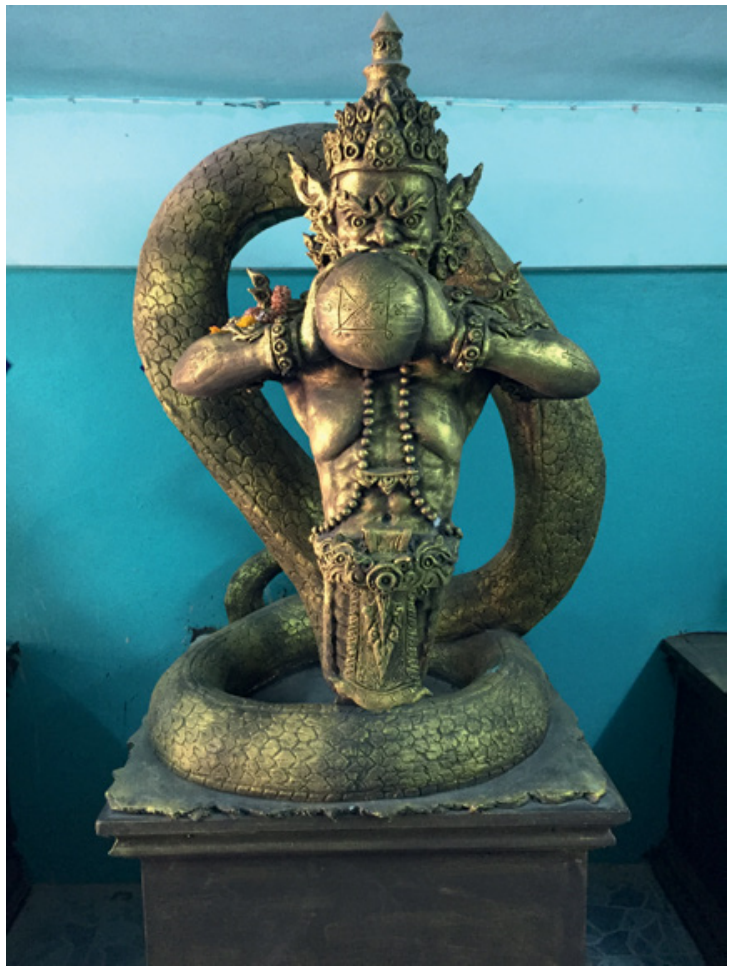

FIGURE 10 Rahu of Wat Bangchak, Nonthaburi 


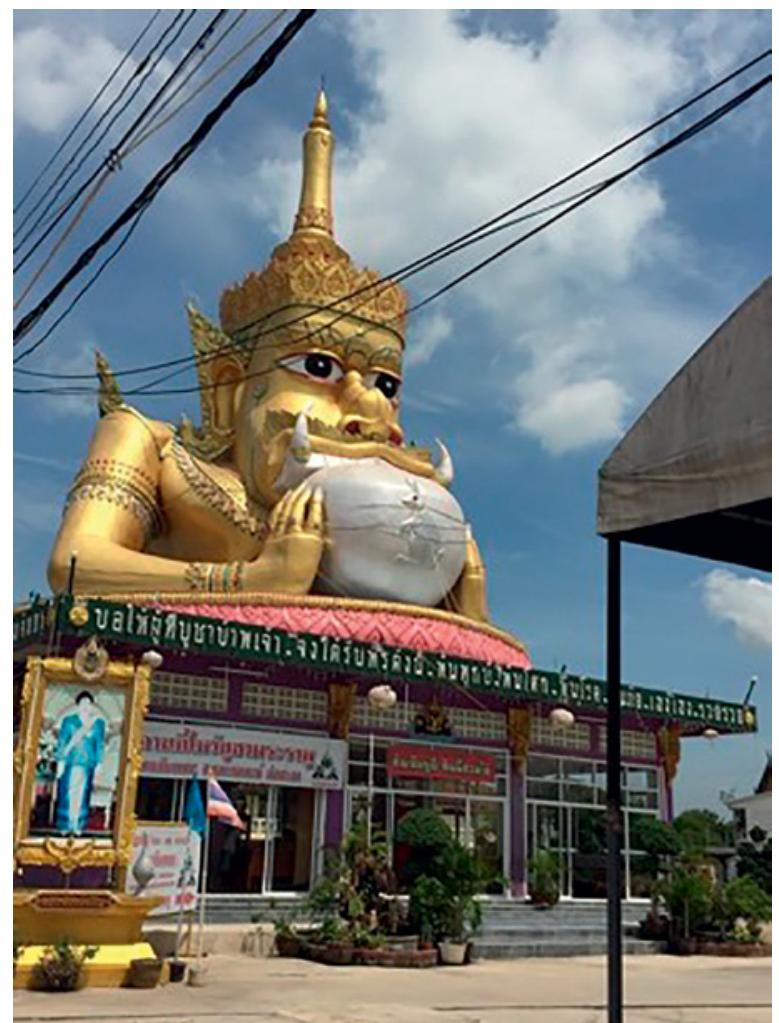

FIGURE 11 Wat Sanamchandr, Chachoangsao

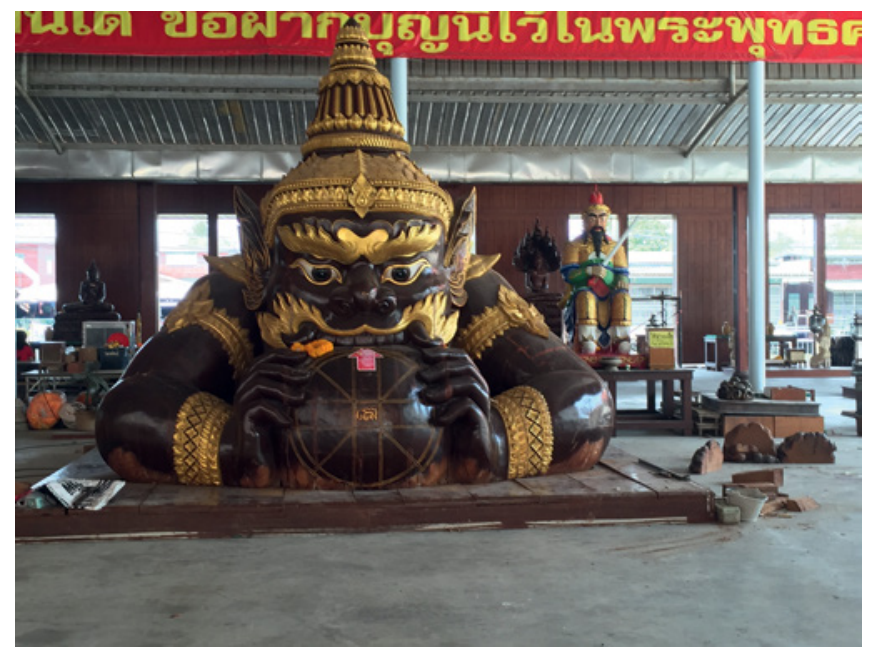

FIGURE 12 Wat Lak Si Rat Samoson, Samut Sakhon 


\subsection{The High-relief Sculpture}

According to the data collection, there are two characteristics which are the sculpture for the demonstration of the holy object and the sculpture for decoration. The creation of these symbols is used only in Rahu with the half body. The author thinks that the creators received influence from the belief in using Asura image as the protector of holistic objects or places. In other words, the image has been adjusted to enhance its attractiveness with a tourism purpose.

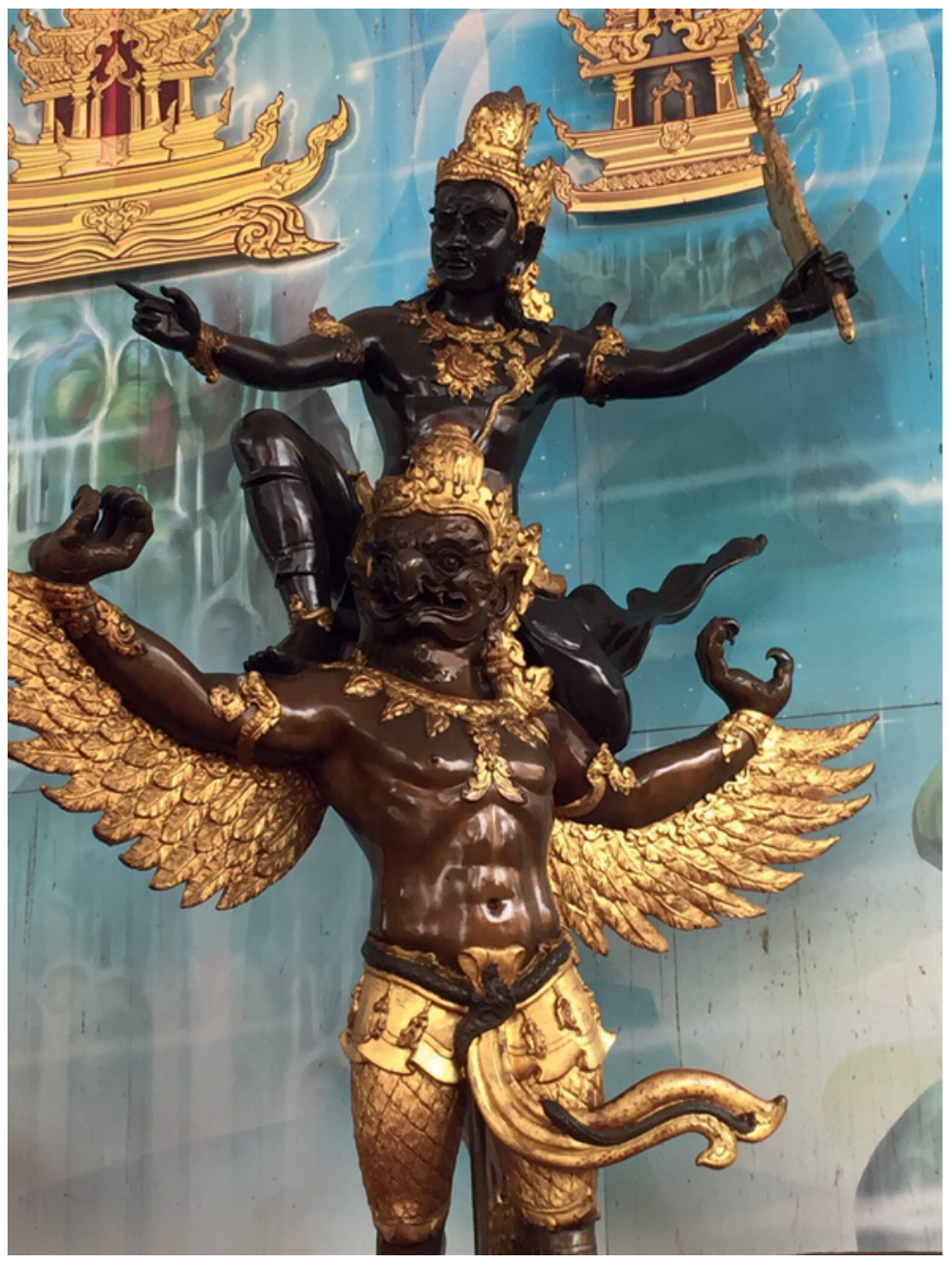

FIGURE 13 Wat Chao Am, Bangkok 


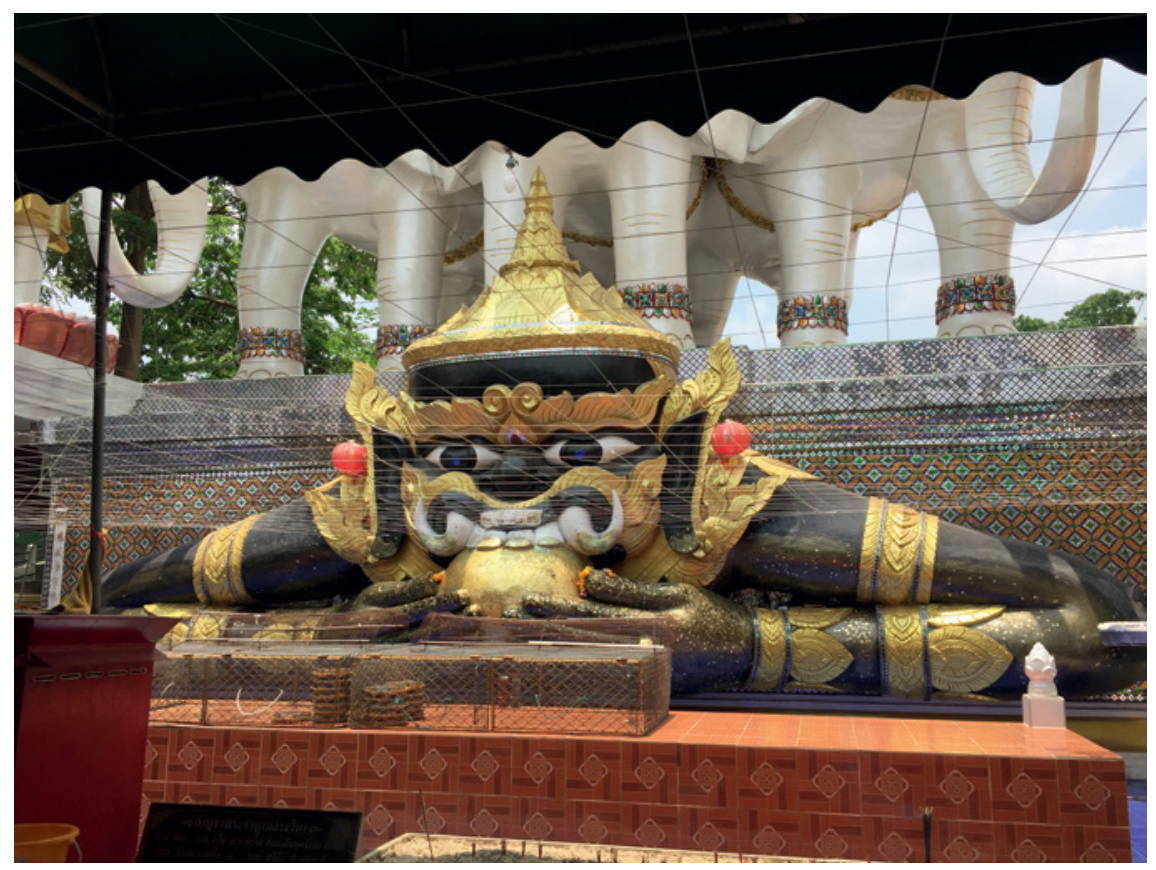

FIGURE 14 Wat Khunchandr, Bangkok

\subsection{Bas-relief or Incised Relief Sculpture}

According to the data collection, there are two characteristics which are the bas-relief on the coin for worship and the bas-relief as the decoration in a religious place. With regard to the coin, the author sees that it is the minimized size of the large sculpture that people widely worship, turning it into an amulet. This is to build income for the symbol creator. As for the bas-relief for decoration, the author regards that these works come from the use of Asura image as the protector of objects or places. The idea complies with the highrelief, which the artists selects for their proficiency; it depends on the demand of the owner or the investor. In terms of incises relief works, the main original model is the coconut shell work of Luang Phor Noi of Wat Srisathong. It can be counted as the building of an amulet for worship.

\subsection{Painting Works of Rahu}

The research found two types, which are Rahu printing works and Rahu in mural paintings. For the printings of Rahu, the author discovered 2 characteristics: religious printing and social phenomenon printing. As for the religious prints, the works are in the form of amulets for worship while the social phenomenon 


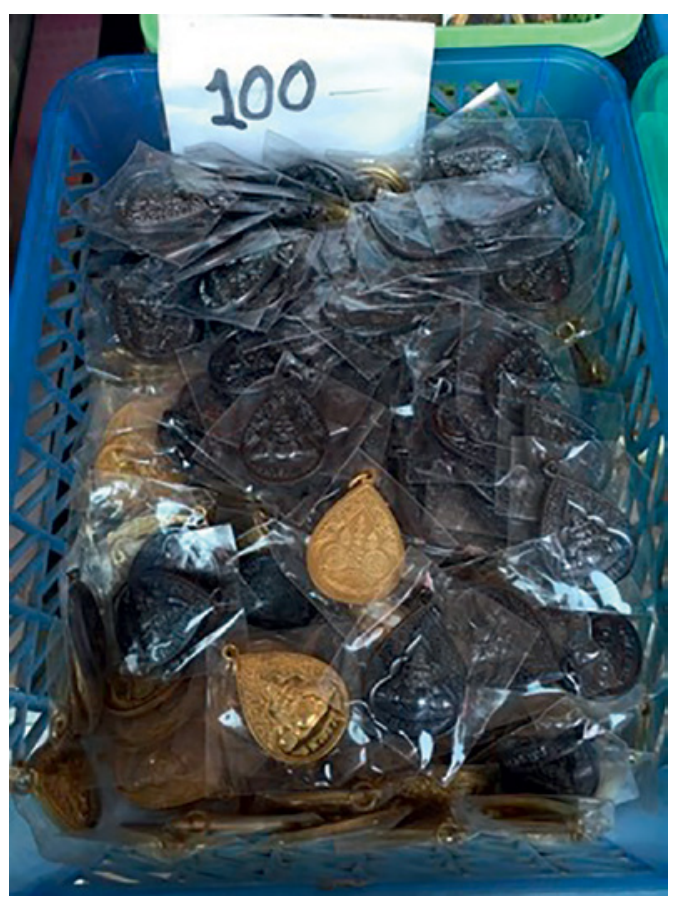

FIGURE 15

Wat Lak Si Rat Samoson

Samutsakhon

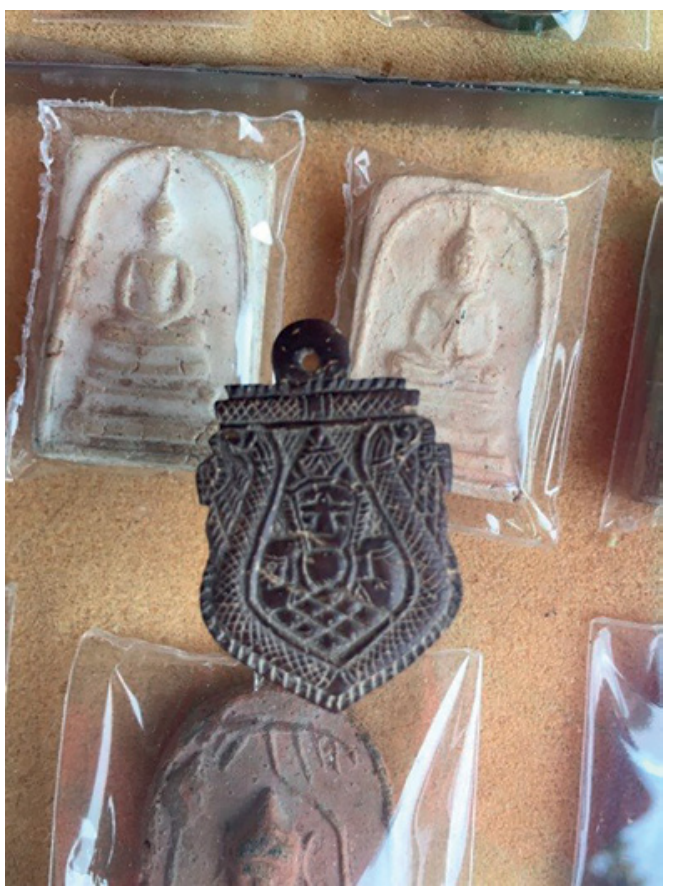

FIGURE 16

Wat Srisathong, Nakhon Pathom 
printing is an image to illustrate the article in the political magazine applied as the tool for sarcasm or a reflection of the deteriorated society. It symbolizes the city where Rahu governs.

The author found 2 characteristics of mural paintings: the mural painting used for religious purposes and the painting used for explaining a social phenomenon. The mural painting used for religious purposes inherits the tradition of Rahu painting for the protection of Buddhist places. In addition, it is to create the identity of the Buddhist place to stand out from other places. The creation of arts attracts visitors; therefore, another reason is for tourism.

The research found that the creation of the Rahu symbol in art was the result of the concept of the Rahu symbol, which incorporates the BrahmanHindu belief and astrology but it is created in the Buddhist context that appears in a Buddhist place. This article reflects the integration of the Rahu belief in Thai art. It is the result of two major social phenomena, namely the merging of beliefs about Rahu to create value and the combination of Rahu beliefs and cultural flow. Thus, the phenomenon of mixing the beliefs about Rahu in Thai art reflects the mental propulsion of the "creators" who want to make Rahu valuable to the "worshipers" who need mental attachment. Both of these purposes have resulted in the creation of the Rahu symbol for worship in Thai society.

Recently, the meaning of the symbol of Rahu in Thai art has diversified. The key factors consist of four components: the concept of astrology in Thai society, the characteristics and circumstances of Buddhism in current Thai society, the role of Rahu as a universal symbol in Thai society and the construction of new definitions of the symbol of Rahu in current Thai society.

Almost everyone in current Thai society has the same understanding of the symbol of Rahu as the deva who represents fear and misery. Thus, the symbol of Rahu has a universal meaning that unifies understanding. Whenever people were frightened and sorrowful, they worshiped the symbol of Rahu, since they had the same perception of its meaning although they came from diverse societies, regions and cultures. This circumstance was reflected in the temple murals that emerged during the crisis period in Thai society. For example, a drawing of Rahu holding a rifle at Wat Saket, Bangkok reflected fear of assassination during political crisis. According to Phra Vicitradhammaphorn the painter wanted to reflect on the events of the suppression of protesters during 2010-2012. There are the deaths, injury and the injured during rallies. 


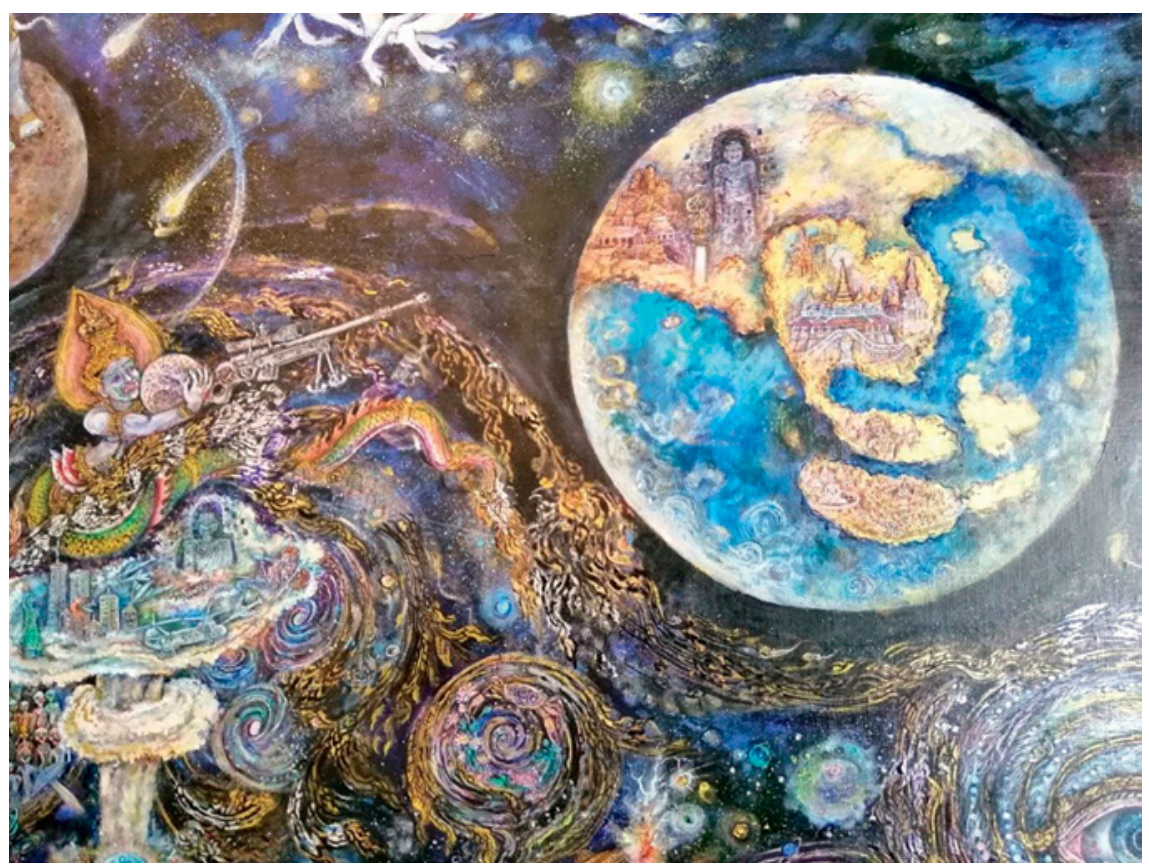

FIGURE 17 Rahu holding a rifle at Wat Saket, Bangkok

From 2005 to 2016 there was a political crisis in Thailand. Political news was reported carefully, particularly during the coup d'etat period when any criticism of the prevailing situation was restricted and any news items that could cause damage to the government were obstructed. For example, the coup leader and the Prime Minister gave an interview regarding negative news reporting and stated that it would harm the government and the administration.

However, though it was difficult to report and criticize the government during the coup d'etat period, it was clear that the negative government administration was damaging the economy and society. This view was presented via the symbol of Rahu. In 2016, the two popular weekly magazines Matichon and the Nation broadcast the New Year headlines with a symbol of Rahu. The magazines also talk about Rahu as the bad situation of Thai economy and politics. This circumstance of using the symbol of Rahu in these two magazines was not a coincidence. The symbol was used to communicate the economic and social problems to the readers as Rahu was widely known as the symbol of misfortune, wickedness and misery.

Thus, the use of Rahu to explain social circumstances based on the Thai social belief in astrology was used as a stratagem to criticize the inadequate performance of the government. Hence, the symbol of Rahu implied criticism 


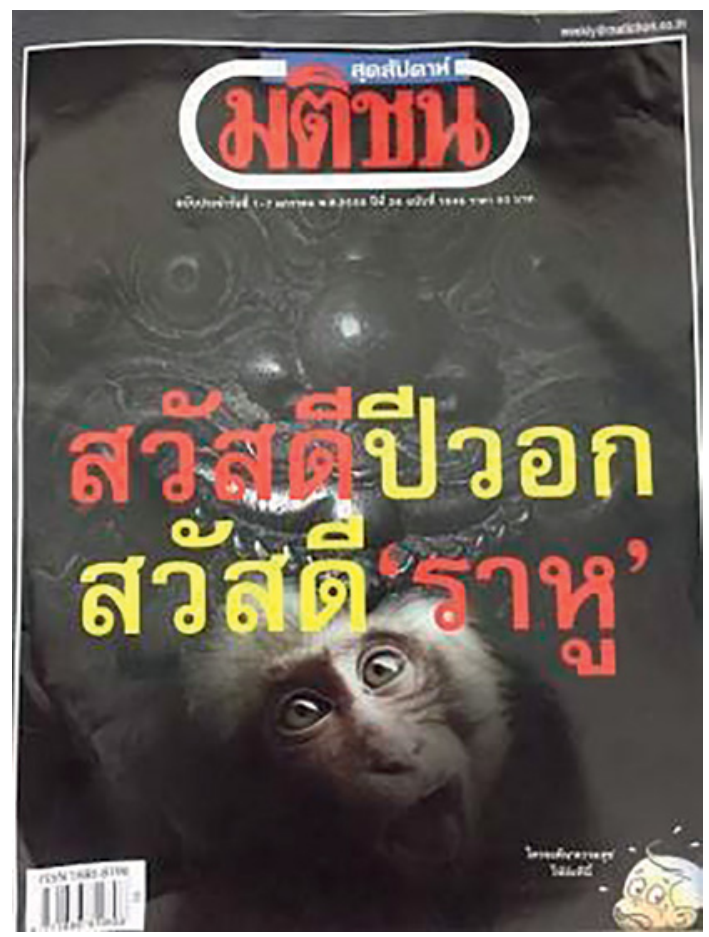

FIGURE 18 Matichon putting the headlines for the New Year with the symbol of Rahu

of the government through belief in astrology and conveyed the meaning to the readers. The government could not take action against the magazine and also fully understood the implications of the artworks.

\section{Creating new Meanings of the Symbol of Rahu in Current Thai Society}

Currently, three new meanings of the symbol of Rahu are generally perceived by the public at large: Rahu as the symbol of an exorcism ceremony, Rahu as the symbol of fortune and Rahu as the symbol of change.

\subsection{Rahu: The Symbol of Warding off bad Luck}

Though, most Thais believe in karma according to Buddhism, there is a belief that good and bad luck are influenced by astrology. Good things happen because of previous good deeds and bad events occur as the result of karma or 
misfortune. However, in the perception of Thai people, Rahu brings bad fortune (Hong Hon Sri Mahapho 2002: 409-432). If a person had bad luck or the astrologer predicted an important misfortune, then the individual was advised to worship Rahu to exorcise the evil spirit and bring good luck.

The meaning of Rahu as a symbol of bad luck is not new in Thai society. In the past, Rahu was considered the cause of disasters and the god was blamed for poor crop yields. However, considering the current context, the scope of meaning was expanded from bad luck in terms of astrology to reflect other difficulties in life. People were well aware that when they had difficulties in life, they had to worship Rahu immediately since they understood that Rahu was the key reason for the difficulty. To worship Rahu was to accept that his power controlled their life. Thus, chanting or worship ceremonies pleased the deva who then removed the obstacles. An exorcism ceremony dispelled the bad luck.

Thus, it is understandable that the increasing circumstances of Rahu heightened implications of insecure situations for people in society. It is perhaps little wonder that the increase of Rahu symbolism reflected the index of social unrest. It seems that in Thailand, the principles of Buddhist doctrine could not resolve the problems in society so the people turned to Rahu for help.

\subsection{Rahu: The Symbol of Fortune}

Recently, the meaning of Rahu as the god of fortune has emerged in Thai society. This meaning was noticed during the economic crisis in 1997 when the symbol of Rahu became very popular at the time of the full solar eclipse in Thailand at the end of 1995. Originally, people worshipped Rahu to dispel bad luck and survive the economic crisis. When they overcame that situation and had more financial security, this heralded the beginning of a new interpretation of Rahu integrated with the existing meaning. Rahu now became the symbol of fortune which implied wealth. The circumstances were reflected through the construction of various attitudes of Rahu. For example, Wat Tamai, Samutsakhon, Wat Tho Yai, Chonburi etc., profiled the symbol of Rahu in the form of a large sculpture and many people visited the temple to pay respect to the Rahu sculpture. With the increase in people, the temple began to organize a Rahu-worship ceremony. As a result, more and more people came to the temple. Later, a new symbol of Rahu was presented as a holy object for sale. This attracted more people to the temple to buy the holy objects to sell online or in the market. As a result, the commercial value of these holy objects increased. Originally, these temples were small situated in a remote area without a surrounding community. Consequently, the temple had a small budget for development. After marketing the symbol of Rahu, many people 


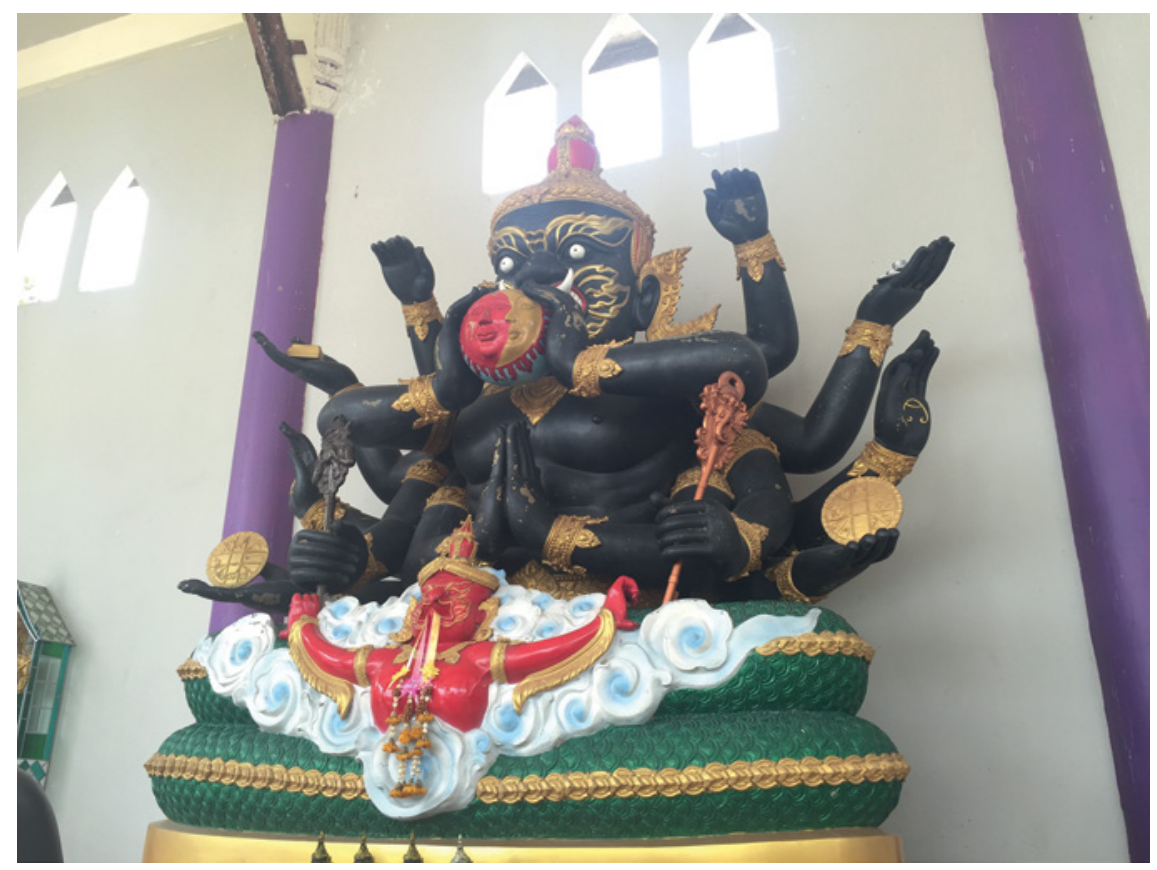

FIgURE 19 Wat Tho Yai, Chonburi

came to visit the temple and it became famous and earned sufficient income for development and expansion.

This case study shows how firstly designing the symbol of Rahu and then integrating belief in the god added value in Thai society. Most temples in Thailand have similar circumstances and the production of symbols might have been developed to make holy objects or souvenirs relating to Rahu.

The interpretation of Rahu as the symbol of fortune might result from the connection of beliefs in Rahu and Vessuvanna the asura as the god of treasure, riches and wealth. Vessuvanna guarded the assets of the world as well as being the leader of the asuras, the god who dominated the four directions. This was the influence of the Tribhumi explaining that there were devas who guarded the four directions or the four keepers of the world in Tawatimsa. This was in accordance with Mahasamaya Sutta and Tribhumi (Fine Arts Department 2003:14) as the existing belief in Thai society. Moreover, Thai people perceived that Rahu and Vessuvanna were asuras so they should have the same influence on wealth and riches. 


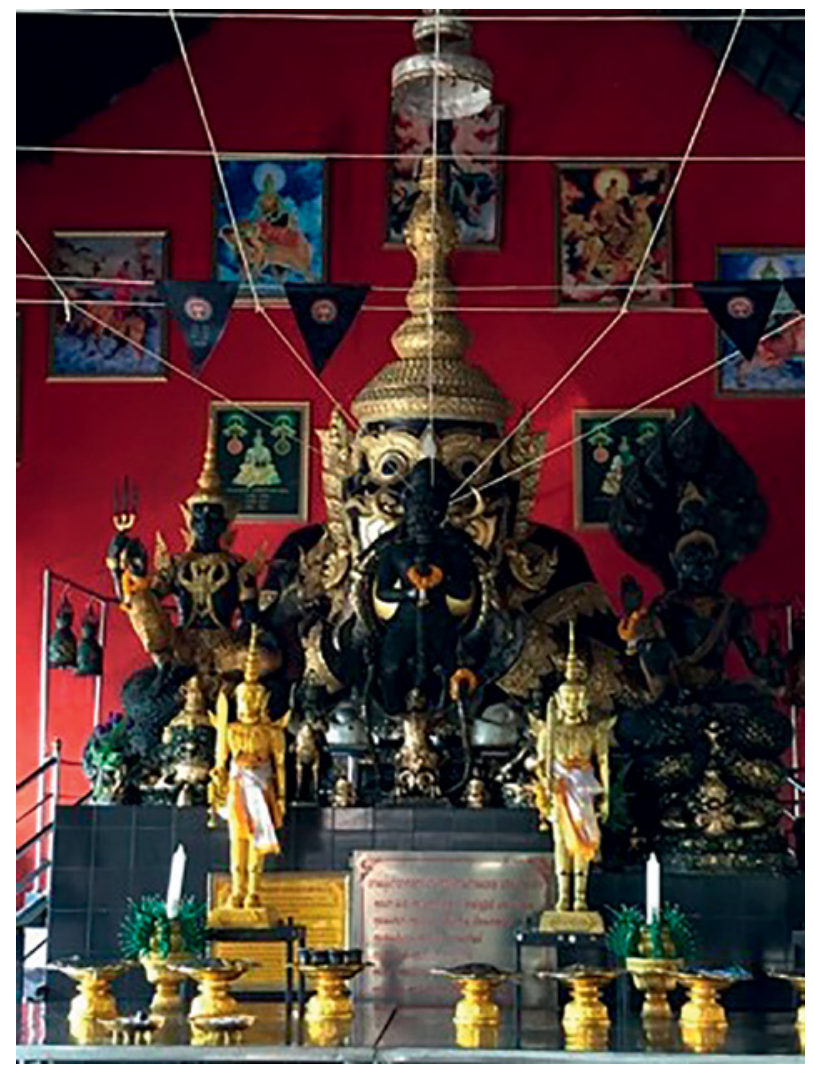

FIGURE 20 Wat Tamai, Samutsakhon

\subsection{Rahu: The Symbol of Transition and Change}

Creation of the meaning of Rahu as a symbol of transition and change was assumed to have resulted from the expansion of the god's role in astrology to predict social change from the position of stars within the signs of the zodiac. When Rahu moved to any zodiac sign it was considered to be a bad sign. In astrology, Rahu represented the symbol of change. Humans are afraid of change or uncertainty so any negative changes were believed to have been caused by Rahu.

The rise of the meaning of Rahu as the symbol of change was very interesting in Thai society, especially symbol development in diverse areas. For instance, using Rahu as a political symbol reflected the idea of negative change. Furthermore, the use of Rahu to symbolize an individual represented that person as someone bad who should be driven from society. 
Thus, the factors behind the development of the symbol of Rahu in art reflected key mechanisms in Thai society. However, artists were influenced by a conceptual insight that fully believed in supernatural power. Nevertheless, as long as Thai society consisted of these four factors, the use of the symbol of Rahu would be maintained in Thai society. Meanwhile, belief in astrology and luck was an essential factor in giving birth to the use of other symbols, apart from the symbol of Rahu in Thai society.

\section{Conclusion}

Temples in Thailand are constantly developing new symbols of Rahu. One of the significant reasons for this is to integrate belief in Rahu to increase the value of holy objects and increase the number of people who visit the temples as pilgrims. When one temple presented a new symbol of Rahu, this played an important role in attracting people to travel to it. Consequently, large sized Rahu art can often be seen in small local temples in rural areas or in small communities.

Thus, the integration of the belief in Rahu to add value to Thai society is very interesting. Field research data indicates clearly that the creation of the symbol of Rahu in art was originally an integration of astrological beliefs, rites and Buddhist commercials. However, the temple utilized the presentation of a large Rahu art display to attract people to visit. Without people, temples cannot survive economically. The highlighting of symbols of devas in modern art and not only the symbol of Rahu has become popular and these portray meanings that mirror the perception of people in our globalized world. This trend is becoming popular and adding more value to the art, similar to the symbol of Rahu.

Therefore, producing the symbol of Rahu is now based on the economic principle of demand which refers to the need to buy products or services at different prices depending upon availability. Demand is comprised of two components - willingness to buy and ability to pay. The rule of demand states "If other factors are stable, demand or the willingness to buy decreases when the price is going up. The demand or the willingness to buy increases if the price is going down." (Mingmaninakin 2008: 24)

In terms of economic principles, another rule is supply. Supply refers to the need to sell products or services by the seller at different prices for the highest profit when other factors are stable. Supply consists of two components; willingness to sell and ability to produce. The rule of supply states "If other factors are stable, supply or the willingness to sell decreases when the price is going 
down. The supply or the willingness to sell increases if the price is going up." (Mingmaninakin 2008: 24)

The increasing production of the symbol of Rahu with higher economic value is an indication of the demand for Rahu by people in society and competition among suppliers to make Rahu products.

One factor for the existence of Rahu in Thai society was the multicultural community that integrated beliefs in Buddhism and animism which finally led to the Rahu-worship ceremony for peace and calm. According to the traditional culture of Thailand, there are two strata of belief: animism and Buddhism, (Terwiel 1994: 1) therefore, the ceremony drives away bad luck by worshipping a supernatural power as the sacred deva based on BrahmanismHinduism that is the part of animism. This worship resolves a bad year (ปีชง) according to Chinese belief. However, the worship of the symbol of Rahu was not identified as any one particular belief but aimed to bless life and dispel bad luck. The development of Rahu art blended and fused together people from different regions and diverse descents such as Thai-Chinese, Thai-Indian and migrant workers in the ASEAN region. The symbol of Rahu played an important role as the social mean and the part of Popular Buddhism in Thai society.

From field data, the creation of the symbol of Rahu in Thai society spread wide in three ways: from the central area to the east and the west, in the remote areas and dispersion in the industrial areas. The first involved spread from central areas to the east such as Chonburi, Chachoengsao and Chantaburi and to the west including Nakhon Pathom, Petchaburi, Ratchaburi and Kanchanaburi. These areas inherited the symbol of Rahu in similar ways, possibly from the Ayutthayan style art in these areas, especially in Petchaburi as contemporary Ayutthayan art. Dispersion was also influenced by Wat Srisa Thong, Nakhon Pathom which was the origin of the ritual ceremony concerning Rahu that aimed to unify Lao people.

Dispersion in the remote areas occurred in central Thailand. Most temples that developed the symbol of Rahu were generally small and difficult to access such as Wat Bang Krang, Nonthaburi or Wat Chong Samae San, Chonburi which has faced severe flooding. The symbol of Rahu encouraged more people to visit the temples and was the spiritual supporter that turned crisis to opportunity with temple development. Presenting the symbol of Rahu was very popular in western areas and the total solar eclipse in 1995 encouraged temples to portray the symbol of Rahu in large sculptures. Consequently, the symbol of Rahu became familiar to people and was integrated into daily life.

Dispersion in the industrial areas possibly began during the economic crisis in 1997. Astrologers coordinated with temples in industrial areas to portray 
the symbol of Rahu as mental support and to dispel bad luck. The belief in Rahu-worship and the astrological predictions originated in the Rahu-worship ceremony and other rites related to Rahu. Importantly, this created a new meaning of the symbol of Rahu as the god of luck to promote economic recovery. As a result, the symbol of Rahu became very popular in industrial areas in central Thailand such as Samut Prakan and Samut Songkhram.

Immigrants and migrant workers who worked in the industrial sector loved traveling to worship the symbol of Rahu. When they had time after work, they went to worship the symbol of Rahu or other holy objects nearby at little cost. This factor exhibited cultural drift and the role of Rahu as the spiritual supporter of people in society.

Thai society developed the symbol of Rahu to respond to social change, consistent with the concept of rites of society. The Princess Maha Chakri Sirindhorn Anthropology Centre (2016) classified the local rites in Thailand into five categories: rites of passage or rites of transition, healing rites, fertility rites, calendrical rites and festive rites/rites for social auspiciousness.

The process of creating the belief in Rahu in Thailand was in accordance with the concept of classifying those rites in Thai society mentioned above. A sub-category was Rahu art existing in Thai society and important factors in profiling the symbol were both the designer and the consumer who respected Rahu.

Both the artist and the consumer had a different purpose for using the symbol of Rahu. The artist aimed to present the symbol of Rahu to become calendrical and festival rites. Thus, Rahu would survive and encourage people to participate in constant and sustainable activities. However, most consumers only regarded Rahu as a healing rite that helped them to dispel misery and illness or assisted with shelter and support in special circumstances. Most consumers already had their main spiritual supporter but some hoped for prosperity in life, so they regarded Rahu as a fertility rite and worshiped the god to beg for prosperity and success in work.

Although the symbol of Rahu was very popular, the designers also produced other symbols of sacred objects as mainstream art which were mostly constructed in the temple. Rahu could not survive individually and Rahu art required the symbolism of the main belief which implied the role of Rahu as the secondary belief. However, it encouraged belief in Rahu to remain secretly in Brahmanism and, in Buddhism, harmoniously with a belief in spiritual and Chinese culture. Furthermore, the emergence of the symbol of Rahu has survived as a tool for measuring anxiety and difficulty of people in society through the original meaning of misfortune and the new meaning of fortune in the current Thai society. 
As aforementioned, it was apparent that the factors of Rahu symbol creation, specifically in Buddhist places in current Thai society, is the strategy for spiritual tourism including spiritual tourism for private tourists, traveling to pay their respects in front of Rahu deity's image, offering 8 black materials or for doing merit, for example, at the same time, the spiritual tourism for a group of tourists is the arrangement of Rau ritual with fixed time and schedule so that people come together.

The spiritual tourism by worshiping Rahu nowadays, if we profoundly consider it, we can see is not the path to escape sufferings in accordance with Buddhist Dhamma and the dynamic worship of Rahu in the present day has largely expanded. This might be the principal reason why the Sangha Supreme Council of Thailand prohibits temples from building large deity images or to distribute or lease amulets (จท $141 / 2560$ ) because the temple will be a commercial place instead of a place for teaching Dhamma.

\section{References}

Bhavakhunworakit, Bhanakul. 2012. Superstitious and Buddhist Commercials in Thai-

Popular Buddhism: Case studies of temples in Nakhon Pathom province. Bangkok: Chulalongkorn University Social Research Institute. (In Thai)

Chandanahom, Wichain. 1966. Lilitdaksabyakorn. Bangkok: Barnnakarn. (In Thai)

Chandrasekharam, Dornadula. 2007. Geomythology of India. < https://www.researchgate.net/publication/249551803_Geomythology_of_India $>$.

Fine Arts Department. 2003. Wat Phutthaisawan. Bangkok: Khuru Sapha Printing Latprao. (In Thai)

Hong Hon Sri Mahapho. 2002. Brahmajati Book. $10^{\text {th }}$ edition. Bangkok: Am-Noay San. (In Thai)

Luang Visaldarunkorn, 1997. Standard Thai Astrology. Bangkok: Inter Print. (In Thai)

Marktawee, Khanittha. 2010. The concept of "Rahu" Demon in Lao Culture in NorthEastern Thailand. Master's thesis, Faculty of Archaeology, Silpakorn University. (In Thai)

Mingmaninakin, Wanrak. 2008. Principles of microeconomics. Bangkok: Thammasat University Press. (In Thai)

Dhammahaso, Phramaha Hansa. 2005. Conjunction of Moon and Sun: Study on Analysis andInterpretation. Graduate School, Mahachulalongkorn Rajavidyalaya University. (In Thai)

Phungpracha, Ekkarin. 2002. Rahu: "The Invented Tradition” of Wat Srisathong. Master's thesis, Faculty of Sociology and Anthropology, Thammasat University. (In Thai) 
Runra, Prasirt. 2014. Suat Nopphakhro Ritual: Dynamism of an Invented Tradition inPresent Thai society. Doctoral dissertation, Department of Thai, ChulalongkornUniversity. (In Thai)

Snodgrass, Andrian.1995. The Symbolism of the Stupa. Ithaca: Cornell University Press. Surasen, Prabhas (trans.). 1997. Anagatavamsa.Bangkok: Surawatna Publications. (In Thai)

Sirikanjana, Pattharaporn. 2014. Buddhism in Thailand: Unity in Diversity. Bangkok: Thammasat University Press. (In Thai)

Princess Maha Chakri Sirindhorn Anthropology Centre. 2016. Rituals, Ceremonies and Local Festivals in Thailand. <http://www.sac.or.th/databases/rituals/definition. php >.

Terwiel, J. Barend. 1994. Monks and Magic. Bangkok: White Lotus. 